\title{
Field Sampling Plan for the Distler Brickyard Superfund Site, Hardin County, Kentucky
}

\author{
Jennifer P. Martin ${ }^{1}$ \\ Lance N. Peterson ${ }^{1}$ \\ Charles J. Taylor ${ }^{2}$
}

Published August 1999

1. Lockheed Martin Idaho Technologies Company, Idaho Falls, Idaho

2. U.S. Geological Survey, Water Resource Division, Louisville, Kentucky

Prepared for the Lockheed Martin Idaho Technologies Company

By Parsons Infrastructure and Technology Group, Inc, Under Subcontract No. C95-175008 and for the

U.S. Department of Energy

Assistant Secretary for Environmental Management

Under DOE Idaho Operations Office

Contract DE-AC07-94ID13223 


\section{DISCLAIMER}

This report was prepared as an account of work sponsored by an agency of the United States Government. Neither the United States Government nor any agency thereof, nor any of their employees, make any warranty, express or implied, or assumes any legal liability or responsibility for the accuracy, completeness, or usefulness of any information, apparatus, product, or process disclosed, or represents that its use would not infringe privately owned rights. Reference herein to any specific commercial product, process, or service by trade name, trademark, manufacturer, or otherwise does not necessarily constitute or imply its endorsement, recommendation, or favoring by the United States Government or any agency thereof. The views and opinions of authors expressed herein do not necessarily state or reflect those of the United States Government or any agency thereof. 


\section{DISCLAIMER}

Portions of this document may be illegible in electronic image products. Images are produced from the best available original document. 
INEEL/EXT-99-00738

August 1999

\section{Field Sampling Plan for the Distler Brickyard Superfund Site, Hardin County, Kentucky}

Approved by:

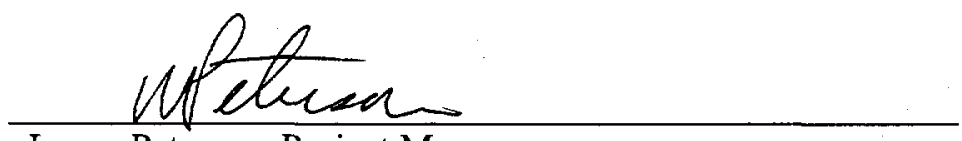

Lance Peterson, Project Manager

Lockheed Martin Idaho Technologies Company

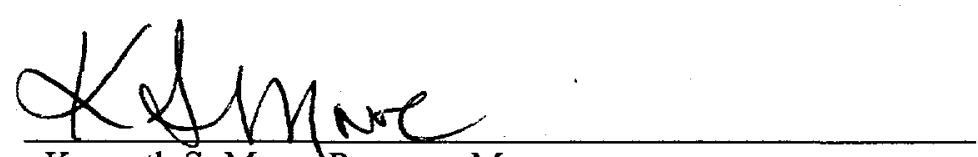

Kenneth S. Moor, Program Manager

Lockheed Martin Idaho Technologies Company

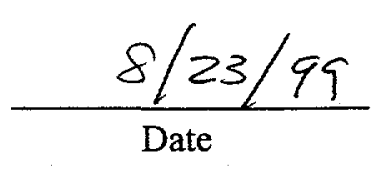

$\frac{8 / 23 / 99}{\text { Date }}$ 



\begin{abstract}
This plan describes the field and analytical activities to be conducted at the Distler Brickyard Superfund Site, Hardin County, Kentucky, in order to evaluate natural attenuation processes within the aquifer system. Sampling will consist of a single round to take place in October 1999. Analytes will consist of the contaminants of concern (chlorinated aliphatic hydrocarbons), electron donors (non-chlorinated organic compounds), oxidation-reduction indicators, and water quality parameters. These activities are conducted in order to evaluate the extent to which natural attenuation processes, in the form of anaerobic reductive dechlorination, may be taking place in the aquifer system. These data will then be used to select the appropriate remediation technology for this site.
\end{abstract}

This plan was prepared in cooperation with the Water Resources Division of the United States Geological Survey and the United States Environmental Protection Agency Water Quality Laboratory in Athens, Georgia. 
.

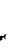

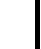




\section{CONTENTS}

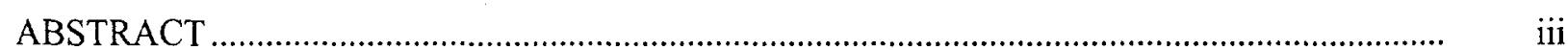

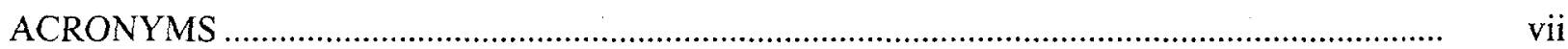

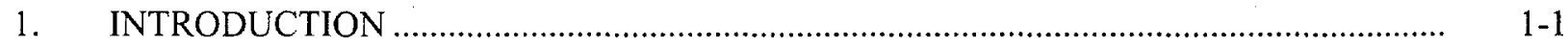

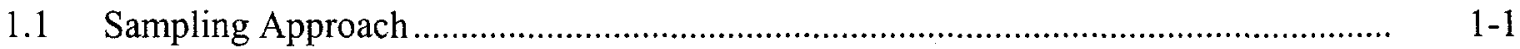

1.2 Anaerobic Reductive Dechlorination ..................................................................

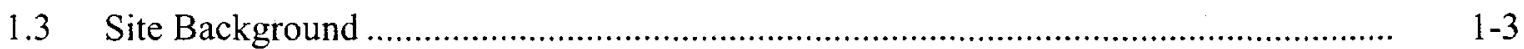

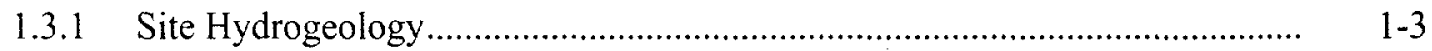

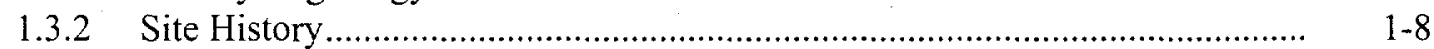

1.3.3 Distribution of Contaminants ..............................................................

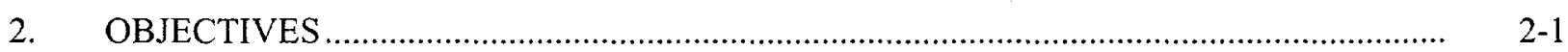

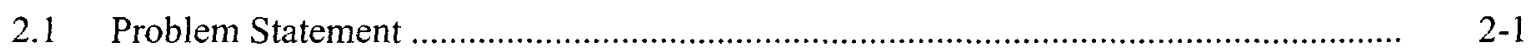

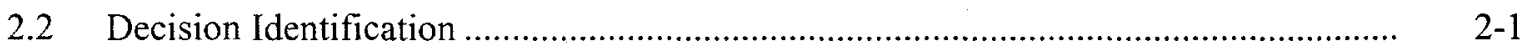

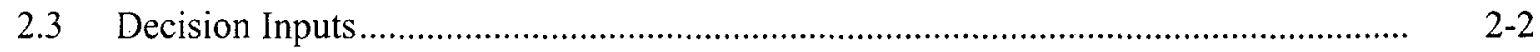

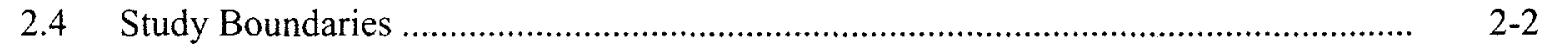

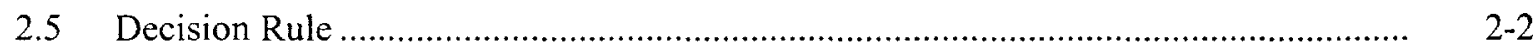

2.5.1 Concentrations of Contaminants of Concern …............................................. 2-2

2.5.2 Electron Donor Concentrations .................................................................. 2-2

2.5.3 Degradation Product Concentrations............................................................ 2-5

2.5.4 Indicator Parameter Concentrations ........................................................... 2-5

2.5.5 Major Cation Concentrations ........................................................ 2-5

2.5.6 Biological Nutrient Concentrations......................................................... 2-5

2.5.7 Water Quality Parameters ................................................................. $2-5$

$2.5 .8 \quad$ 1,4-Dioxane Concentrations .................................................................. 2-6

2.6 Decision Error Limits ................................................................................. 2-6

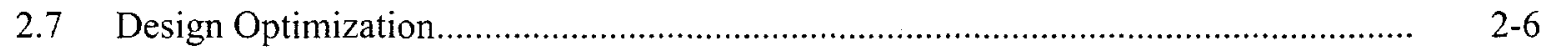

3. SAMPLING LOCATION AND FREQUENCY …......................................................

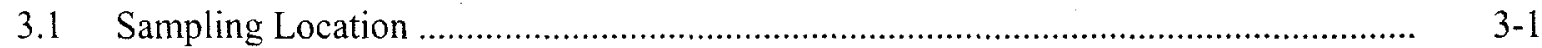

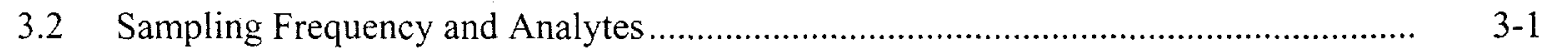

4. SAMPLING EQUIPMENT AND PROCEDURES …..................................................... 
5. SAMPLE HANDLING AND ANALYSIS _.............................................................

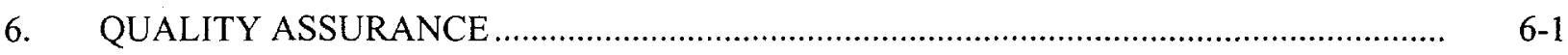

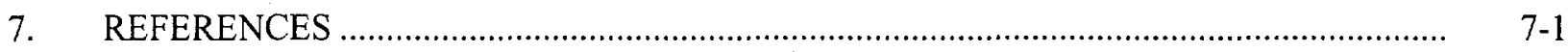

\section{FIGURES}

1-1. Location of the Distler Brickyard Superfund Site......

$1-2$

1-2. Monitoring locations, stratigraphic designations, and extent of contamination at the Distler Brickyard Site (Modified from USGS, 1992).

1-3. Chemical and biological transformation pathways for TCE and 1,1,1-TCA.

Modified from Barbee (1994).

1-4. Redox potentials for various redox reactions showing the optimal range for ARD

(Bouwer 1994 and Wiedemeier et al. 1997).

1-5. Cross-section of the FGA and CGA.

\section{TABLES}

1-1. Contaminants of concern detected at the Distler Brickyard Site 1995-1997

(USGS, in preparation)

2-1. Project responsibilities.

2-2. Decision inputs.

3-1. Sampling locations.

$3-1$

5-1. Sample volume, preservation, and holding time.

6-1. Quality assurance samples. 


\section{ACRONYMS}

\begin{tabular}{|c|c|}
\hline ARD & anaerobic reductive dechlorination \\
\hline BTEX & benzene, toluene, ethylbenzene, and xylene \\
\hline $\mathrm{CAH}$ & chlorinated aliphatic hydrocarbons \\
\hline CGA & Coarse Grained Alluvium \\
\hline COD & chemical oxygen demand \\
\hline DCA & dichloroethane \\
\hline DCE & dichloroethene \\
\hline DOC & dissolved organic carbon \\
\hline EMB & ethylmethylbenzene \\
\hline EPA & U.S. Environmental Protection Agency \\
\hline FGA & Fine Grained Alluvium \\
\hline FS & feasibility study \\
\hline INEEL & Idaho National Engineering and Environmental Laboratory \\
\hline IPB & iso-propylbenzene \\
\hline LMITCO & Lockheed Martin Idaho Technologies Company \\
\hline MAH & monocyclic aromatic hydrocarbon \\
\hline $\mathrm{MCL}$ & maximum contaminant levels \\
\hline MTBE & methyl-tertiary-buty-ether \\
\hline PCE & tetrachloroethene \\
\hline PPB & propylbenzene \\
\hline RA & removal action \\
\hline RI & remedial investigation \\
\hline TCA & trichloroethane \\
\hline TCE & trichloroethene \\
\hline
\end{tabular}


TCFE trichlorofluoroethylene

USGS U.S. Geological Survey

VC vinyl chloride

VOC volatile organic compound 


\section{Field Sampling Plan for the Distler Brickyard Superfund Site, Hardin County, Kentucky}

\section{INTRODUCTION}

A sampling event is being conducted at the former Distler Brickyard Superfund Site, Hardin County, Kentucky (Figure 1-1), in order to evaluate the significance of natural attenuation processes in the aquifer. The data collected will be used to determine the appropriate remediation strategy for this site.

This plan was developed from information presented in the following documents on the Distler Brickyard Site:

- $\quad$ Anderson, W. R. and A. K. Bomberger, 1986, Remedial Investigation Report, Distler Brickyard West Point, Kentucky, NUS Corporation, Unpublished technical report, U.S. Environmental Protection Agency Region 4, Atlanta, Georgia.

- EPA, 1998, Five Year Review Report Distler Brickyard Superfund Site, Hardin County, Kentucky, Unpublished technical report, U.S. Environmental Protection Agency Region 4, Atlanta, Georgia.

- $\quad$ Fekete, A. and W. S. Butterfield, 1991, Site Investigation, Distler Brickyard Site, West Point, Kentucky, Unpublished technical report, U.S. Environmental Protection Agency, Work Assignment Number 3-499, Region 4, Atlanta, Georgia.

- $\quad$ OHM Corporation, 1989, Recovery and Injection Well Testing, Distler Brickyard EPA Superfund Site, Unpublished technical report, U.S. Environmental Protection Agency Region 4.

- $\quad$ OHM Corporation, 1990, Basis of Design Report at Distler Brickyard Site, West Point, Kentucky, Unpublished technical report, OHM Project Number J6504, U.S. Environmental Protection Agency Region 4.

- USGS, 1992, Unpublished letter to the US EPA Region 4, Atlanta, Georgia

- USGS, in preparation, Investigation of Trends in Volatile Organic Chemicals in Ground Water at the Former Distler Brickyard Superfund Site, Hardin County, Kentucky, 1995 1997, USGS Water Resources Division Draft Report.

\subsection{Sampling Approach}

The goal of the sampling is to collect site-specific data to evaluate the presence of natural attenuation and anaerobic reductive dechlorination (ARD) processes in this system. This consists of three specific goals:

1. Determine whether ARD is occurring in the Fine Grained Alluvium (FGA) Aquifer

2. Identify the distribution and evaluate transport of contaminants in the Coarse Grained Alluvium (CGA) Aquifer

3. Identify whether natural attenuation processes are occurring in the CGA. 


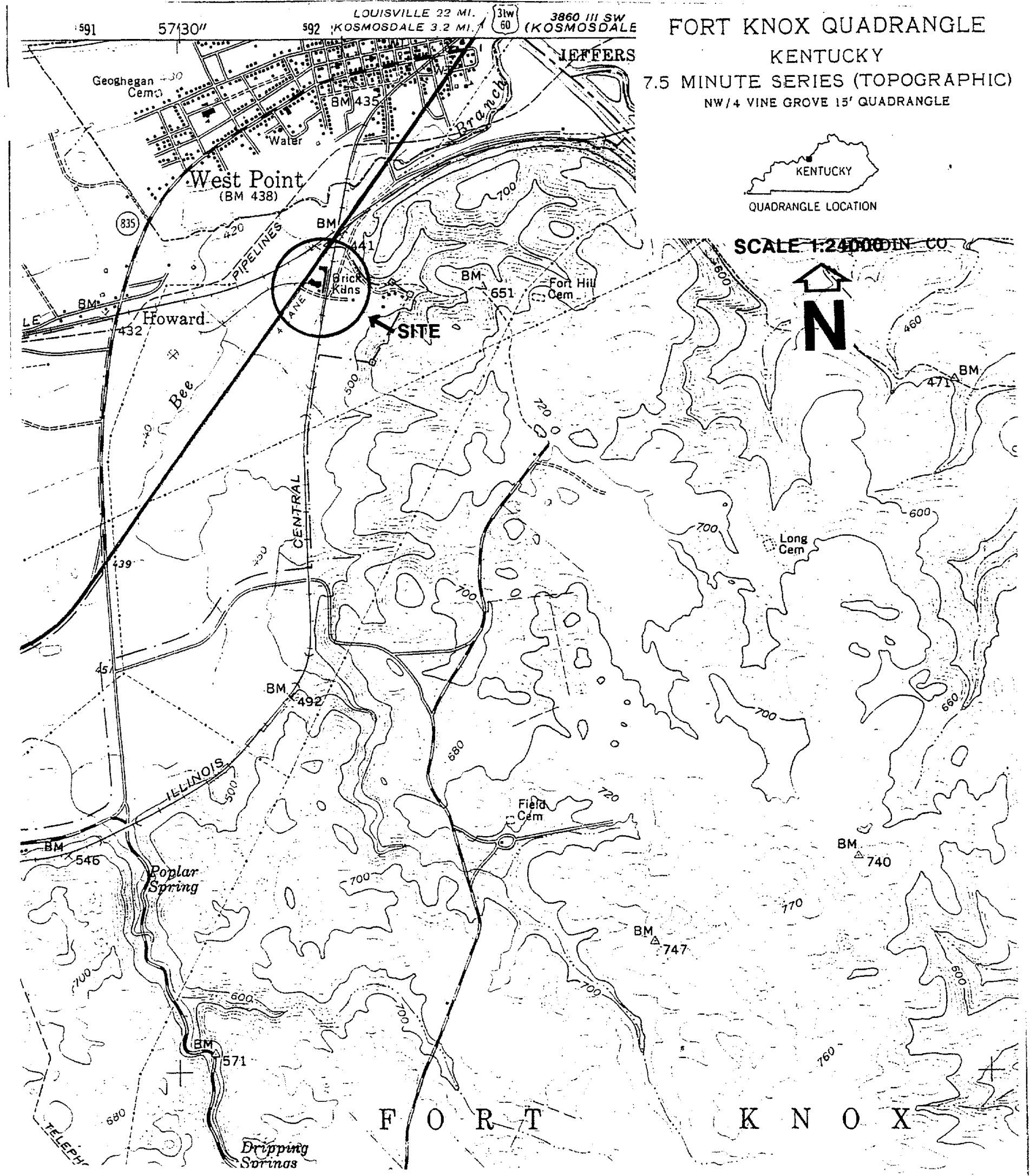

Figure 1-1. Location of the Distler Brickyard Superfund Site. The Ohio River is located on the northwest edge of the city of West Point. 
Sampling will be conducted in a single sampling event and will include 4 wells in the FGA (GW-11, GP-5, GP-7, and GW-4), 6 wells in the CGA (GW-3, MW-1, MW-2, MW-3, RW-4, and UDBP-7), and one well that is screened across both units (PZ-4) (Figure 1-2). The monitoring locations in the FGA include two areas of known contamination (GW-4 and GW-11) and two monitoring locations between the two (GP-5 and GP-7), for which no historical data are available. Monitoring in the FGA will allow for the determination of the extent of contamination and the geochemical conditions in order to address Goal 1. The monitoring locations, GW-3, GW-11, PZ-4, and MW-1, form an axial cross-section through the source area located at GW-11 and the plume downgradient of this source area. This section will provide information as to the fate and transport of contaminants originating at GW-11 downgradient into the CGA (Goal 2). It will also allow for the detection of changes in geochemical conditions in the observed downgradient direction that may affect the degradation of contaminants. Monitoring in the CGA will also consist of a transect (MW-1, MW-2, MW-3, UDBP-7, and MW-4) downgradient of the contamination at GW-11. Both transects will define the distribution of contaminants and the geochemical conditions within the CGA (Goal 2). This information will be used to determine whether natural attenuation processes are occurring in the CGA (Goal 3).

\subsection{Anaerobic Reductive Dechlorination}

Chlorinated aliphatic hydrocarbons (CAHs), such as trichloroethene (TCE) and 1,1,1-trichloroethane (1,1,1-TCA), are relatively oxidized and are thus not readily susceptible to oxidative degradation. For this reason, they were believed to be non-biodegradable until degradation of tetrachloroethene (PCE) and TCE was observed in 1983 laboratory studies by Bouwer and McCarty (1983). The degradation mechanism was not oxidation but ARD. ARD of CAHs is the microbially mediated redox reaction in which chlorine atoms are sequentially removed and replaced with hydrogen atoms. The chemical and biological transformation pathways for ARD of TCE and 1,1,1-TCA are illustrated in Figure 1-3. Through this process, TCE and 1,1,1-TCA are degraded to ethene and chloroethane (Barbee 1994).

In $\mathrm{ARD}$, the $\mathrm{CAH}$ acts as an electron acceptor. An electron donor, in the form of natural organic matter or non-chlorinated organic compounds, must be present in order for ARD to proceed. In addition to an abundant supply of electron donor, competing electron acceptors must be absent. Electron acceptors that provide the most energy will be used preferentially. The order in which inorganic electron acceptors are typically utilized is: oxygen, nitrate, manganese (IV), iron (III), sulfate, and carbon dioxide. The optimal range for ARD is sulfate-reducing and methanogenic conditions (Figure 1-4). Therefore, in order for ARD of TCE and 1,1,1-TCA to be energetically favorable, competing electron acceptors must be absent, or electron donor must be present in sufficient concentrations to meet competing electron acceptor demand.

\subsection{Site Background}

\subsubsection{Site Hydrogeology}

The Distler Brickyard Site is located in unconsolidated alluvial and glacial outwash deposits. The alluvium consists of two hydrostratigraphic units: the upper FGA and the underlying CGA (Figure 1-5). Early investigations conceptualized the FGA and CGA as a single aquifer, in which regional groundwater flow was to the northwest (Anderson and Bomberger 1986). More recent investigations suggest that groundwater in the FGA flows to the west and to the northwest in the CGA, indicating that the two units are separate aquifers (OHM 1989, de la Pena 1989; Fekete and Butterfield 1991). The FGA is approximately $12 \mathrm{~m}(40 \mathrm{ft})$ thick and consists of silty clays with sand and peat lenses. Depth to water is approximately $7.6 \mathrm{~m}(25 \mathrm{ft})$ 


\section{EXPLANATION}

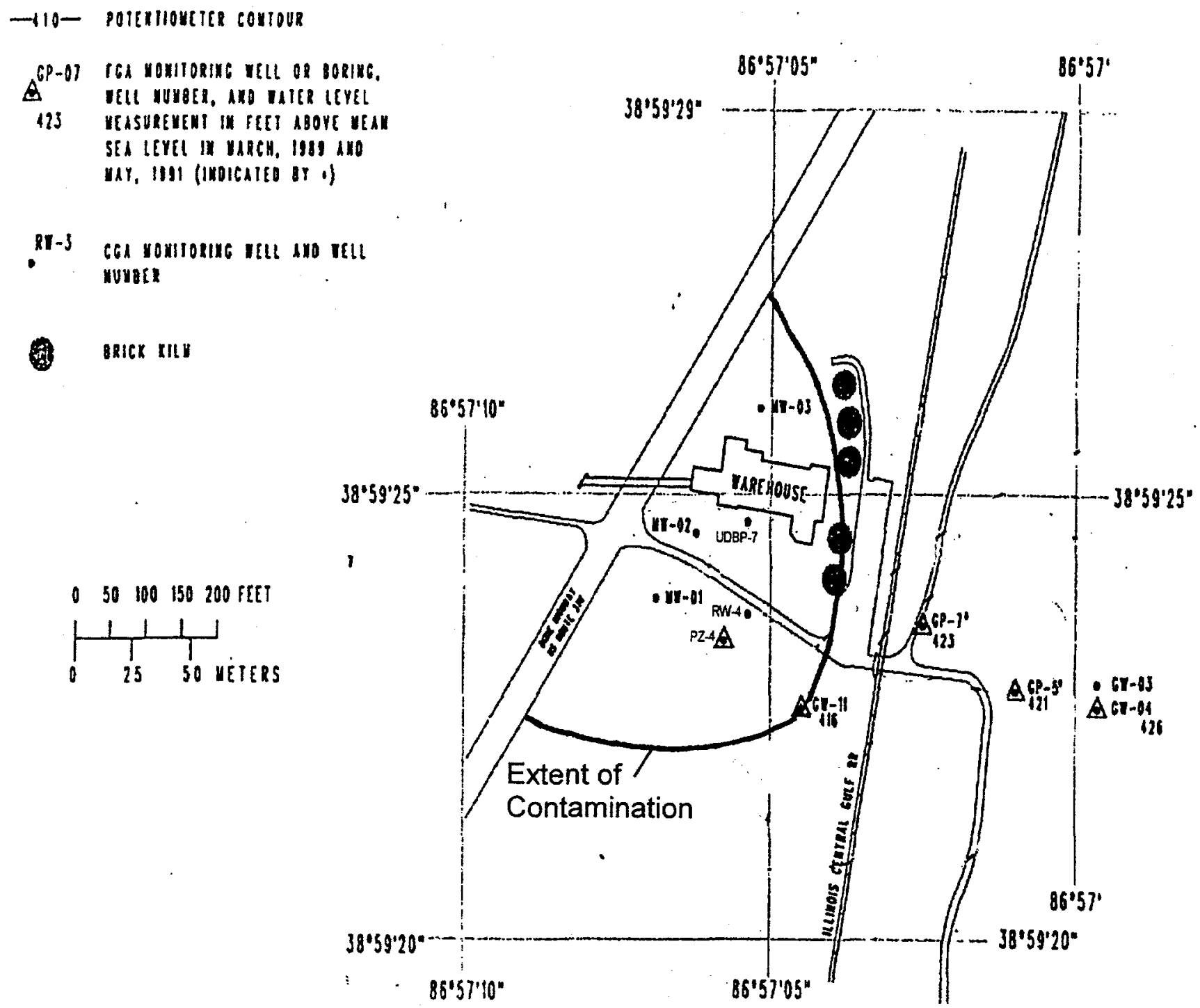

Figure 1-2. Monitoring locations, stratigraphic designations, and extent of contamination at the Distler Brickyard Site. The extent of contamination is based on the presence of dissolved hydrocarbons in monitoring wells. Another possible source area may exist in the vicinity of GW-4. Regional groundwater flow is to the northwest (Modified from USGS, 1992). 


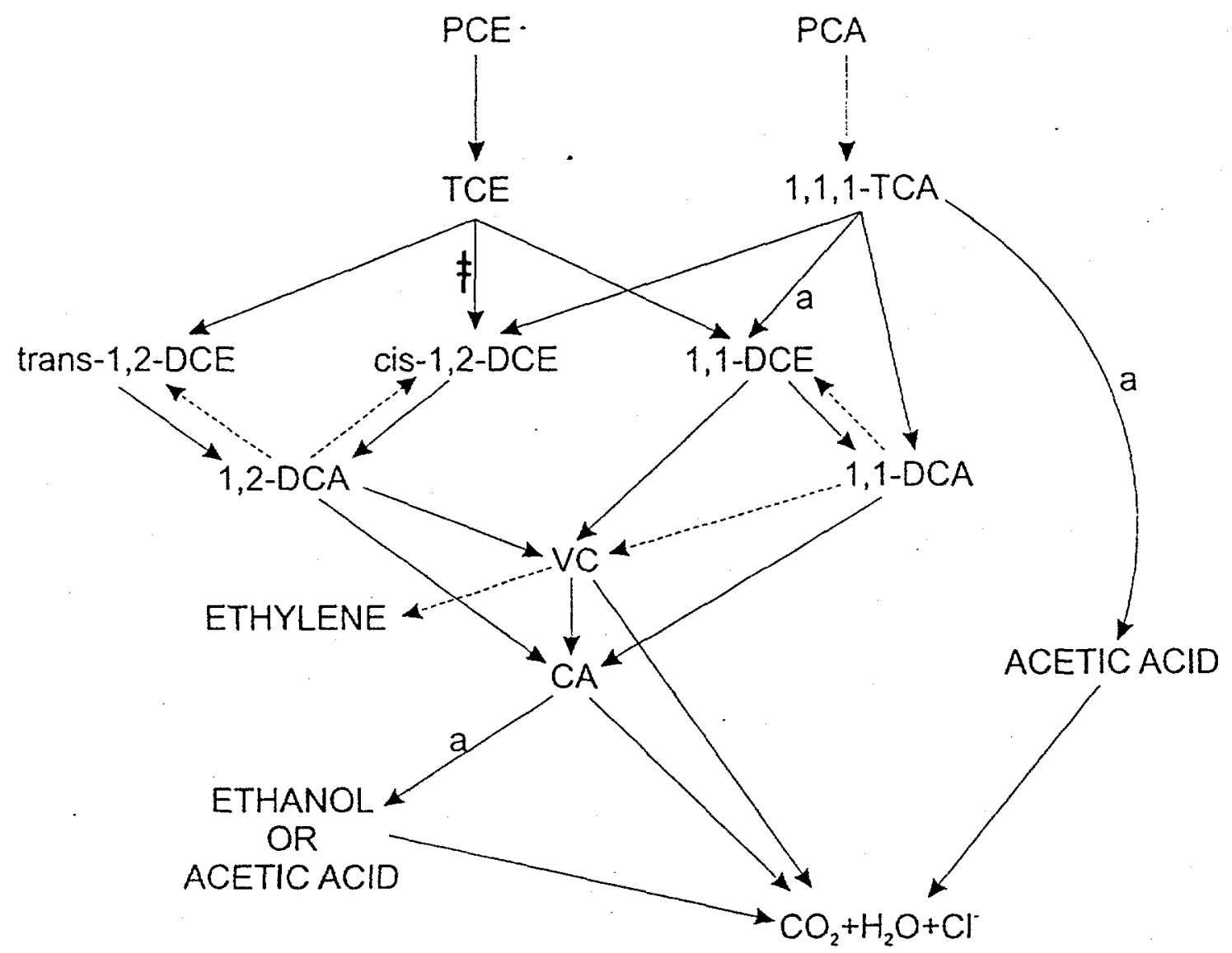

EXPLANATION

PCA = TETRACHLOROETHANE

PCE $=$ TETRACHLOROETHYLENE

1,1,1-TCA $=1,1,1-$ TRICHLOROETHANE

TCE = TRICHLOROETHYLENE

1,1-DCA $=1,1-\mathrm{D} \mid \mathrm{CH}$ LOROETHANE

1,2-DCA $=1,2-$ DICHLOROETHANE

$1,1-D C E=1,1-D I C H L O R O E T H Y L E N E$ cis 1,2-DCE $=$ cis 1,2-DICHLOROETHYLENE

trans 1,2-DCE $=$ trans 1,2-DICHLOROETHYLENE

VC $=$ VINYL CHLORIDE

$C A=C H L O R O E T H A N E$

$\mathrm{CO}_{2}=$ CARBON DIOXIDE

$\mathrm{H}_{2} \mathrm{O}=$ WATER

$\mathrm{Cl}^{\circ}=$ CHLORIDE ION

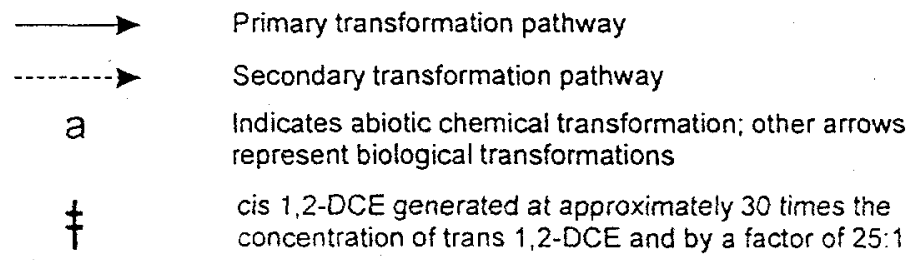

Figure 1-3. Chemical and biological transformation pathways for TCE and 1,1,1-TCA. Modified from Barbee (1994). 
Redox Potential $\left(\mathrm{Eh}^{\circ}\right)$

in millivolts at $\mathrm{pH}=7$

and temperature $=25^{\circ} \mathrm{C}$

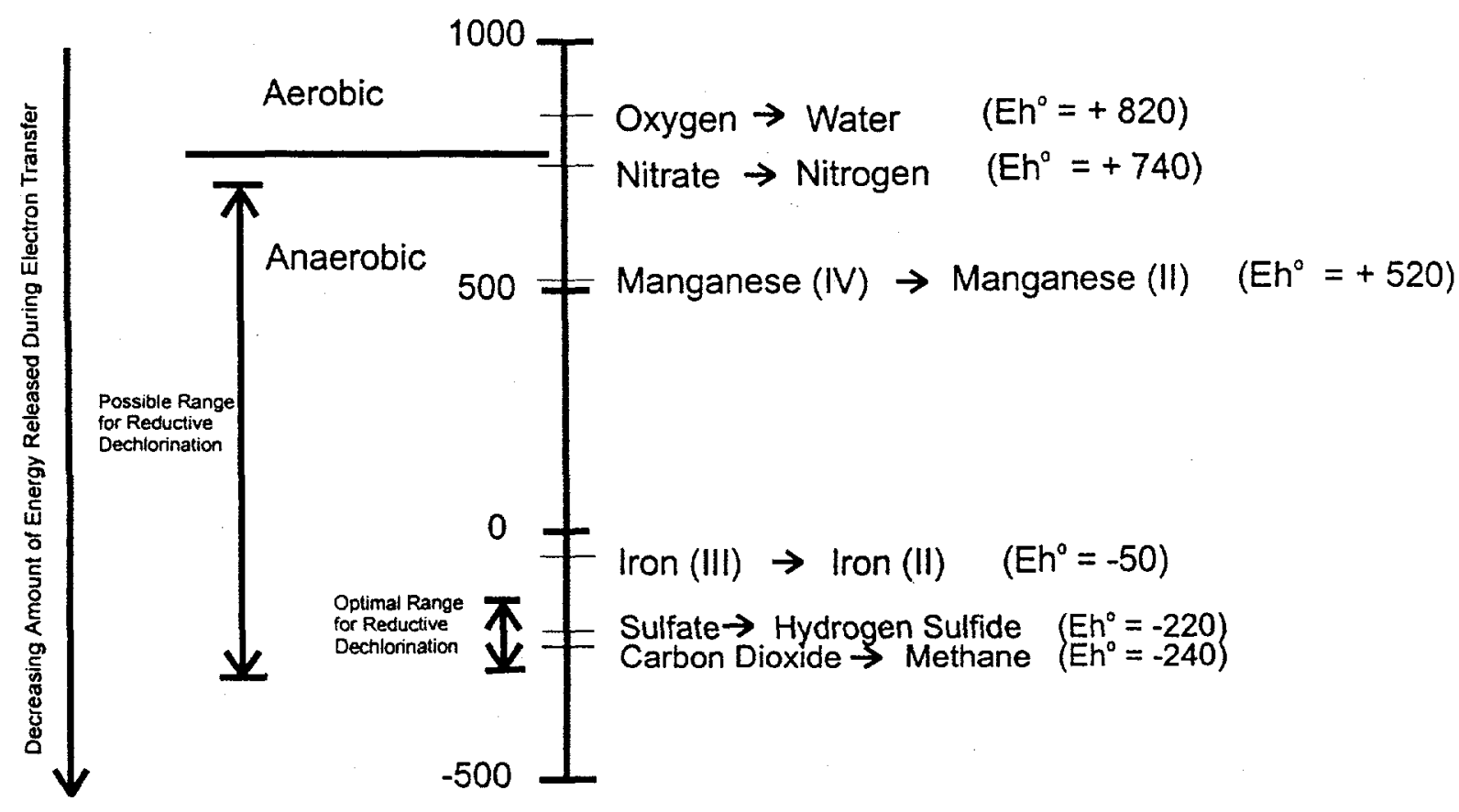

Figure 1-4. Redox potentials for various redox reactions showing the optimal range for ARD (Bouwer 1994 and Wiedemeier et al. 1997). 


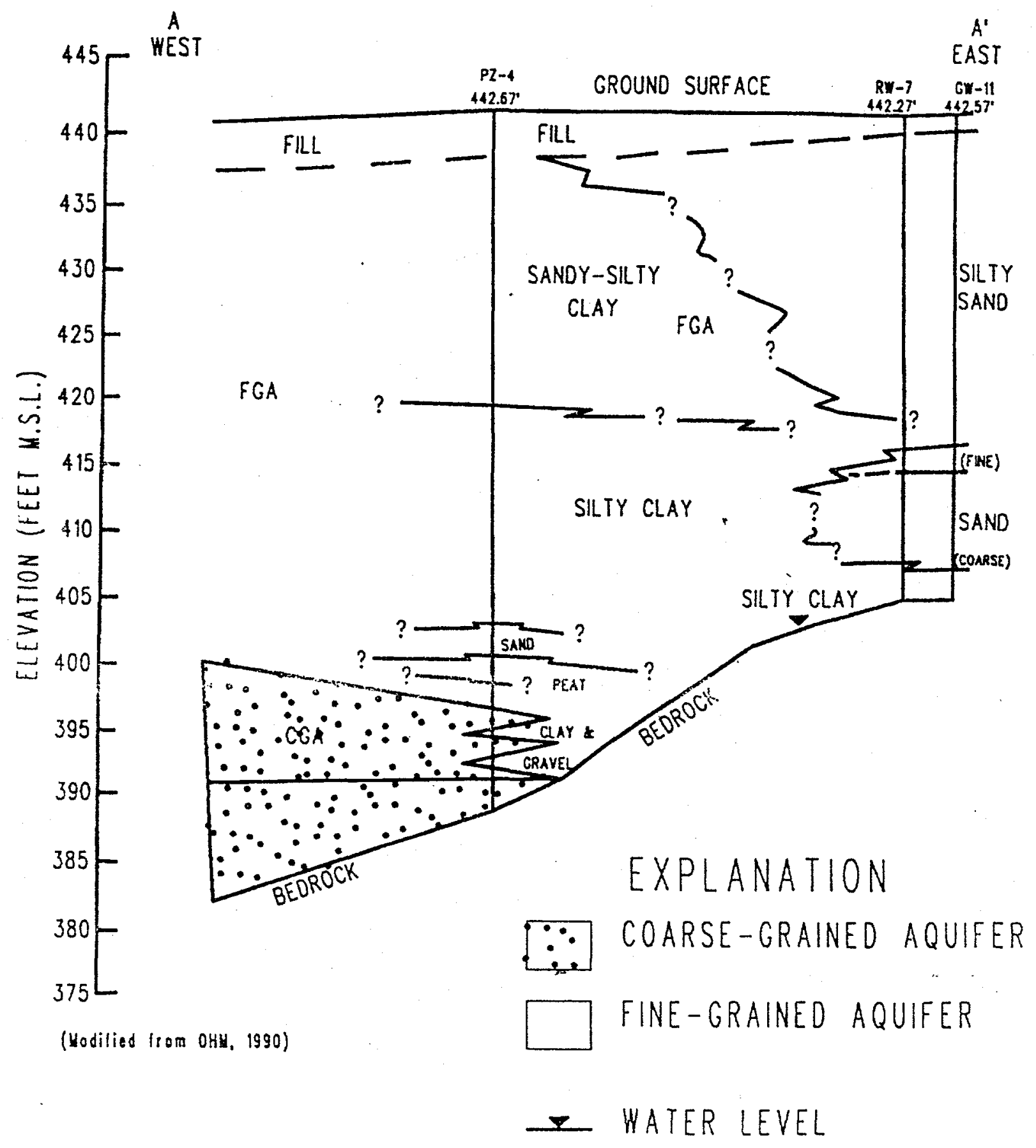

Figure 1-5. Cross-section of the FGA and CGA. 
below ground surface and the aquifer is recharged by infiltration of precipitation (OHM 1989, USGS in preparation). Hydraulic conductivities in the FGA range from $10^{-8} \mathrm{~cm} / \mathrm{s}$ (Anderson and Bomberger 1986) to $10^{-4} \mathrm{~cm} / \mathrm{s}$ (OHM 1989).

In the western portion of the site, the FGA is underlain by the CGA ( 0.4 to $6 \mathrm{~m}$ [1.5 to $20 \mathrm{ft}$ ] thick), which is composed of coarse sand and gravel (de la Pena 1989, Duffey et al. 1983). Depth to water in the

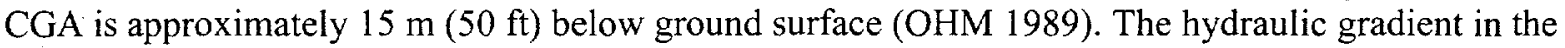
CGA is approximately $0.0027-0.0063$ to the northwest (OHM 1989). Hydraulic conductivities in the CGA range from $10^{-5}$ to $10^{-3} \mathrm{~cm} / \mathrm{s}$ (Anderson and Bomberger 1986), and the aquifer is in hydraulic connection with the Ohio River (USGS 1992). The CGA is a highly productive aquifer and a major source of groundwater for the region (Brown and Lambert 1963, Kepferle and Sable 1977).

\subsubsection{Site History}

The Distler Brickyard Site is located in northern Hardin County, Kentucky (Figure 1-1). The 28-ha (70-acre) site is a former brick manufacturing plant that was used as a waste recycling and storage facility between 1976 and 1979. In 1982, 2,310 drums were removed from the site, approximately $60 \%$ contained toxic, corrosive, volatile, or flammable substances. Following this removal action, the site was placed on the National Priorities List (Anderson and Bomberger 1986).

A remedial investigation (RI) and feasibility study (FS) were conducted between 1985 and 1986, to determine the nature and extent of contamination and necessary clean-up measures for the site. The U.S. Environmental Protection Agency (EPA) published a Record of Decision in 1986 specifying the following remedial action (RA) activities (EPA 1998):

- Excavation of contaminated soil

- Extraction and treatment of contaminated groundwater

- $\quad$ Operation and maintenance of a groundwater treatment system.

Excavation of $382 \mathrm{~m}^{3}\left(500 \mathrm{yd}^{3}\right)$ of contaminated soil was completed in October 1988 , and construction of the groundwater treatment system began in 1989 (OHM 1990). There is no documentation of soil removal from the area around GW-4, another potential source area. Results from the groundwater treatment system indicate that most of the contaminants are located in the FGA, which because of its relatively low hydraulic conductivity $\left(10^{-4}\right.$ to $\left.10^{-8} \mathrm{~cm} / \mathrm{s}\right)$ exhibits low flow rates (EPA 1998). For this reason, advective transport of contaminants through the FGA to the CGA is slow. Thus, removal of contaminants by groundwater extraction and treatment may not be an effective remediation method for this system.

\subsubsection{Distribution of Contaminants}

The Distler Brickyard Site was operated as a storage facility, in which drums of waste were stored aboveground. For this reason, the sources of contamination at the site are a result of drums spilling or leaking onto the soil surface and subsequently infiltrating to the water table. Groundwater sampling during 1983 through 1985 indicated that groundwater in the vicinity of GW-11 is the most highly contaminated at the site. At this time a contaminant plume was identified with the source area located near GW-11 (Figure 1-2) (Anderson and Bomberger 1986). Another potential source area exists near GW-4 where CAHs were found in soil samples. 
The contaminants of concern include CAHs (TCE and 1,1,1-TCA and degradation products), monocyclic aromatic hydrocarbons (MAHs) (i.e., petroleum hydrocarbons), and ketones (Table 1-1). The distribution and concentrations of contaminants indicate that geochemical conditions differ between the two aquifer units. The conditions in the FGA appear to be more conducive to ARD of CAHs. MAHs and ketones are located in the FGA in the vicinity of GW-11. As more dense CAHs infiltrate through the FGA into the CGA, the MAHs and ketones provide a non-chlorinated carbon source that promotes dechlorination of the CAHs (Anderson and Bomberger 1986). The characteristics in the FGA that would favor ARD include anaerobic conditions and the presence of electron donor (petroleum hydrocarbons). The evidence for ARD of CAHs in the FGA includes:

- The absence of CAHs TCE and PCE, and the decrease in 1,1,1-TCA in the FGA

- The presence of the degradation product chloroethane in the FGA

- The widespread occurrence of intermediate degradation products dichloroethene (DCE) and dichloroethane (DCA) in both the FGA and CGA

- The predominance of cis-DCE and 1,1-DCA, the biologically-favored degradation products, over trans-DCE and 1,1-DCE (Barbee, 1994; USGS in preparation).

The conditions in the CGA appear to be less favorable for ARD. The groundwater may be oxygenated due to recharge from the Ohio River and electron donors may be absent. This interpretation is supported by the presence of primary contaminants PCE, TCE, and 1,1,1-TCA in the CGA and the absence of the degradation product chloroethane. The absence of petroleum hydrocarbons also suggests oxidizing conditions (USGS in preparation).

Table 1-1. Contaminants of concern detected at the Distler Brickyard Site 1995-1997 (USGS, in preparation).

\begin{tabular}{ll}
\multicolumn{1}{c}{ CAHs } & \multicolumn{1}{c}{ MAHs } \\
\hline Chloroethane & Ethylbenzene \\
$1,1-\mathrm{DCA}$ & Ethylmethylbenzene (EMB) \\
$1,2-\mathrm{DCA}$ & Iso-propylbenzene (IPB) \\
$1,1-\mathrm{DCE}$ & Propylbenzene (PPB) \\
cis-1,2-DCE & Methyl-tertiary-butyl-ether (MTBE) \\
trans-1,2-DCE & $1,2,3$-Trimethylbenzene (TMB) \\
Tetrachloroethylene (PCE) & $1,3,5$-TMB \\
$1,1,1-\mathrm{TCA}$ & Styrene \\
$1,1,2-\mathrm{TCA}$ & Toluene \\
TCE & Xylene \\
Vinyl Chloride (VC) & \\
Chloroform & \\
Trichlorofluoroethylene (TCFE) & \\
\hline
\end{tabular}




\section{OBJECTIVES}

The objectives of this sampling event are described using the EPA's Guidance for the Data Quality Objectives Process (1994). The purpose of this process is to determine the type, quality, and quantity of data necessary to address the problem in question.

\subsection{Problem Statement}

The purpose of this step is to provide a brief description of the remediation problem to be addressed and identify the project team.

The groundwater at the Distler Brickyard Site is contaminated with CAHs and MAHs (Figure 1-2). Sampling conducted during 1995 through 1997 found concentrations of the CAHs TCE, cis-DCE, and 1,2-DCA exceeding maximum contaminant levels (MCLs). Also, concentrations of the MAHs ethylbenzene, toluene, and xylene were detected above MCLs. The decline in concentrations of primary contaminants TCE and 1,1,1-TCA over time in the FGA along with the presence of degradation products suggests that ARD may be taking place. Geochemical conditions in the CGA, in contrast to those in the FGA, do not appear to be conducive to ARD. The goal of this sampling event is to determine the extent to which ARD is taking place in this system.

This sampling event is a cooperative effort between the US Geological Survey (USGS), the EPA, and the Idaho National Engineering and Environmental Laboratory (INEEL). This sampling event will be conducted over an approximately 2 to 3 week period in October 1999. The project responsibilities are presented in Table 2-1.

\subsection{Decision Identification}

The purpose of this step is to identify the decision to be made based on the data collected.

The decision to be made is whether or not natural attenuation processes in the form of ARD are occurring in the aquifer system. Based on this decision, the possible actions are to enhance the natural biodegradation through the addition of an electron donor, to monitor the unenhanced natural processes, to continue with the selected pump and treat technology, or to choose an alternative remediation strategy.

Table 2-1. Project responsibilities.

\begin{tabular}{lcl}
\hline Functional Role & Organization & \multicolumn{1}{c}{ Contact Person } \\
\hline Field Sampling & USGS & Charles Taylor \\
& & $502-493-1931 ;$ cjtaylor@usgs.gov \\
Sample Analysis & EPA & Nardina Turner \\
& & $404-562-8566 ;$ turner.nardina@epamail.epa.gov \\
Data Analysis & INEEL & Lance Peterson \\
& & $208-526-9738 ; \ln @$ inel.gov \\
\hline
\end{tabular}




\subsection{Decision Inputs}

The purpose of this step is to identify the inputs to the decision discussed in the previous step. The decision inputs are identified in Table 2-2. These inputs have been selected based on previous field evaluations of ARD of CAHs. The precision values in Table 2-2 represent the maximum allowable value required to make a decision. The selected analytical method must meet or exceed these requirements.

\subsection{Study Boundaries}

This step specifies the spatial and temporal boundaries of the study. The study area identifying the wells included in this sampling event is presented in Figure 1-2. Samples will be collected from two hydrostratigraphic units: the FGA and CGA (Table 3-1). The study will consist of a single groundwater sampling event focused on existing wells. No new wells will be installed to support this sampling event.

\subsection{Decision Rule}

This step integrates the outputs from the previous steps into a statement that would enable the decision-maker to choose among alternative actions. The decision of whether or not ARD is occurring is based on a synthesis of the results of the analyses specified in Table 2-2. Sections 2.5.1 through 2.5.8 outline the specific analyte groups and provide summaries of interpretation criteria. Identification of ARD as a significant process relies on the integration of all the results outlined in these sections. The required precision for each analysis is presented in Table 2-2 and a summary of the evaluation approach for each parameter is given below.

\subsubsection{Concentrations of Contaminants of Concern}

The contaminants of concern are TCE and 1,1,1-TCA. The distribution of these contaminants will be evaluated in the FGA and CGA and with respect to known source areas and groundwater flow conditions at the site as described in Section 1.1. The distributions of TCE and 1,1,1-TCA in the FGA and CGA will be compared to the distributions of electron donors, degradation products, and oxidationreduction indicators to assess the significance of $A R D$ in this system.

\subsubsection{Electron Donor Concentrations}

Non-chlorinated organic compounds (MAHs and ketones) have been identified in the FGA in the vicinity of GW-11 (Anderson and Bomberger 1986). It is possible that these non-chlorinated organic compounds act as an electron donor facilitating ARD of TCE and 1,1,1-TCA. Naturally occurring organic carbon in the FGA (occurring as peat lenses) may act as an additional electron donor source. In order for TCE and 1,1,1-TCA to be reduced through ARD, an adequate supply of electron donor must be present. The concentration of electron donor will be approximated by measuring the chemical oxygen demand (COD) and dissolved organic carbon (DOC).

The presence of electron donor in the FGA indicates that ARD may not be limited by a lack of electron donor. The absence of electron donor and the presence of TCE and 1,1,1-TCA indicate that ARD could be limited by a lack of electron donor. The absence of electron donor and the absence of TCE and 1,1,1-TCA could indicate that the process of ARD has already consumed the electron donor. 
Table 2-2. Decision inputs.

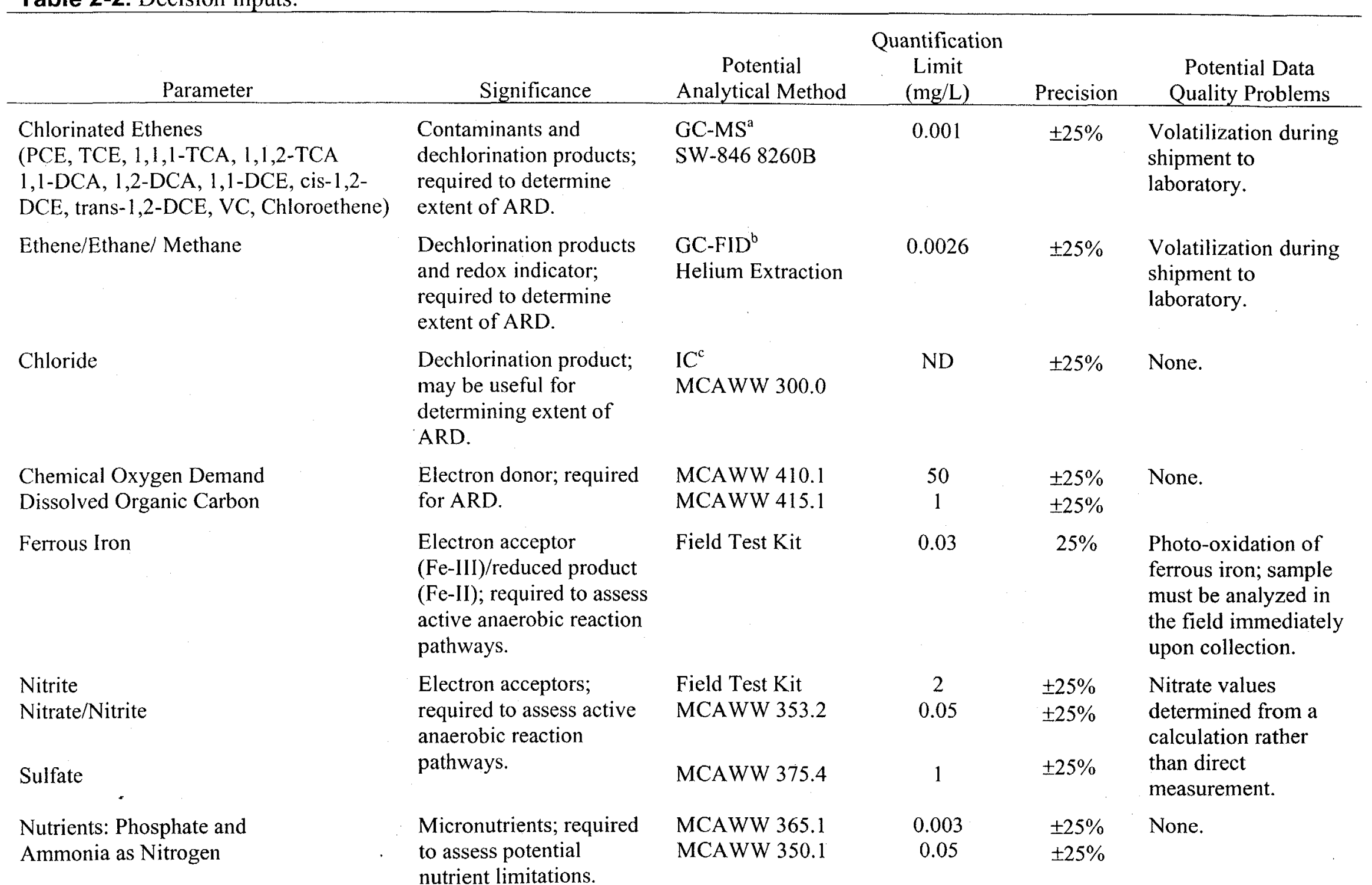


Table 2-2. (continued).

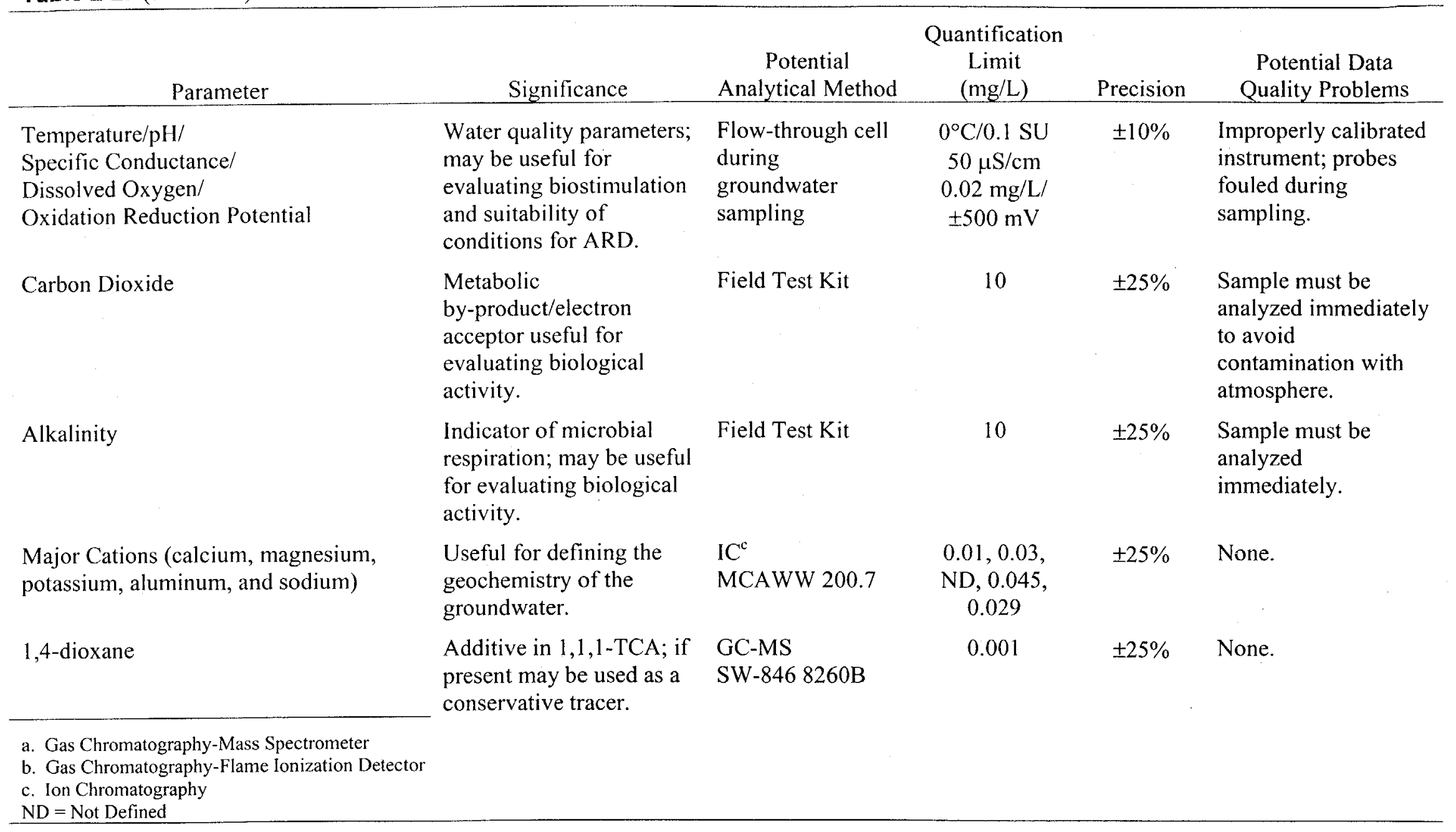




\subsubsection{Degradation Product Concentrations}

The degradation pathways and products of the ARD of TCE and 1,1,1-TCA are presented in Figure 1-3. The absence of degradation products, together with the presence of parent compounds, indicates that ARD is not occurring. The presence of degradation products indicates they were either codisposed with the contaminants of concern or they may be a result of the ARD of TCE and 1,1,1-TCA. The presence of cis-DCE and 1,1-DCA in concentrations significantly greater than those of trans-DCE and 1,1-DCE may indicate that ARD of TCE and 1,1,1-TCA is occurring.

\subsubsection{Indicator Parameter Concentrations}

Indicator parameters are used to support the above data by defining the geochemical conditions in the aquifer. There are two types of indicator parameters: oxidation-reduction (redox) and biological activity indicators.

2.5.4.1 Oxidation-Reduction Indicators. Oxidation-reduction indicators include dissolved oxygen, nitrate, ferrous iron, manganese, sulfate, and methane. As described in Section 1.2, microorganisms will use electron acceptors that provide the most energy. The order in which electron acceptors are utilized is: oxygen, nitrate, manganese (IV), iron (III), sulfate, and carbon dioxide. Therefore, in order for ARD to be energetically favorable, competing electron acceptors must be absent. Complete ARD generally occurs in sulfate-reducing and methanogenic conditions. The most favorable conditions for ARD of TCE and 1,1,1-TCA would include the absence of dissolved oxygen, nitrate, manganese (IV), and sulfate, and the presence of iron (II) and methane.

2.5.4.2 Biological Activity Indicators. Carbon dioxide and alkalinity can be used as indicators of biological activity. Carbon dioxide is produced as a result of mineralization during ARD (Figure 1-3) and of bio-oxidation of organics (denitrification, sulfate reduction, and fermentation) (Drever 1988). Alkalinity is another measure of carbon dioxide concentrations. Zones where ARD is occurring in the FGA should show higher carbon dioxide and alkalinity concentrations than those in the CGA where ARD is not occurring.

\subsubsection{Major Cation Concentrations}

Major cations to be monitored include calcium, magnesium, sodium, aluminum, and potassium. These data will be used to define the geochemical conditions in the aquifer.

\subsubsection{Biological Nutrient Concentrations}

Biological nutrients include ammonia and phosphate. A lack of these nutrients in the aquifer may inhibit microbial growth and the extent to which ARD can take place.

\subsubsection{Water Quality Parameters}

Water quality parameters include temperature, $\mathrm{pH}$, specific conductance, and redox potential. These parameters are used to support the above data in defining the geochemical conditions in the aquifer. 


\subsubsection{1,4-Dioxane Concentrations}

1,4-Dioxane is a stabilizer added to 1,1,1-TCA to prevent degradation. Recent observations have shown that it may be more mobile and less susceptible to degradation than CAHs. ${ }^{a}$ For this reason, if it is present in the 1,1,1-TCA at the Distler Brickyard Site, it may be useful in assessing the extent of degradation of the 1,1,1-TCA. If 1,4-dioxane is present and behaves conservatively, it will be present in higher concentrations further downgradient than 1,1,1-TCA if ARD of 1,1,1-TCA is occurring. If this is the case, the concentrations of 1,4-dioxane will be used to estimate the first order biodegradation rate using the Wiedemeier et al. (1996) method.

\subsection{Decision Error Limits}

The purpose of this step is to specify appropriate performance goals for limiting uncertainty in the data. The required precision for each parameter is presented in Table 2-2. These values were based on the precision required to make a decision and the available analytical methods. In general, a groundwater sampling event conducted to screen for the presence or absence of ARD does not require precision less than $25 \%$.

\subsection{Design Optimization}

This step identifies the most effective sampling and analysis strategy that satisfies the data quality objectives. Sampling locations were chosen to meet the goals identified in Section 1.1. The sampling and analysis strategy and procedures are presented in Sections 4 and 5. Sampling and analysis activities will be performed in accordance with established USGS procedures (Koterba et al. 1995) and US EPA. standard operating procedures (EPA 1996).

a. Cleary, R. W., 1999, personal communication to J. P. Martin from R. W. Cleary 


\section{SAMPLING LOCATION AND FREQUENCY}

\subsection{Sampling Location}

The wells to be sampled are presented in Table 3-1. The locations of the selected wells are presented in Figure 1-2.

The sampling locations were selected in order to meet the goals identified in Section 1. Wells GW-11 and GW-4 represent areas of known contamination in the FGA. GP-5 and GP-7 are used to determine the extent of contamination and geochemical conditions in the FGA. The monitoring locations GW-3, GW-11, PZ-4, RW-4, and MW-1 form an axial section through the plume. This axial section will allow for the determination of the fate and transport of contaminants from the source area at GW-11 into the CGA, specifically whether or not ARD is occurring along this flowpath. CGA monitoring locations $\mathrm{MW}-1, \mathrm{MW}-2$, UDBP-7, and MW-3 form a transect perpendicular to the direction of groundwater flow and contaminant migration from GW-11. This transect will allow for the determination of conditions within the CGA.

\subsection{Sampling Frequency and Analytes}

The selected wells will be sampled in a single sampling event. The analytes are presented in Table 2-2.

Table 3-1. Sampling locations.

\begin{tabular}{ccl}
\hline Well Location & Stratigraphic Designation & Justification from Section 1 \\
\hline GW-04 & FGA & Possible Source Area \\
GW-11 & FGA & Source Area/Axial \\
GP-5 & FGA & FGA conditions \\
GP-7 & FGA & FGA conditions \\
PZ-4 & Transitional & Axial \\
MW-1 & CGA & Axial/Transect \\
RW-4 & CGA & Axial \\
GW-03 & CGA & Axial \\
MW-2 & CGA & Transect \\
UDBP-7 & CGA & Transect \\
MW-3 & CGA & Transect \\
\hline
\end{tabular}




\section{SAMPLING EQUIPMENT AND PROCEDURES}

Sampling activities will be conducted in accordance with the National Water-Quality Assessment Program (NAWQA) Ground-Water Data-Collection Protocols and Procedures (Koterba et al 1995). All groundwater samples will be collected using a Grundfos Rediflo 2 submersible pump fitted with Teflon tubing. Wells to be sampled will be purged prior to sampling by pumping until field water quality parameters such as specific conductance, $\mathrm{pH}$, temperature, and dissolved oxygen have equilibrated (stabilized), or the difference between successive field measurements is $10 \%$ or less. This stabilization indicates that the pump is withdrawing fresh groundwater. The field water quality parameters will be monitored using a Hydrolab $\mathrm{H}_{2} \mathrm{O}$ multiparameter water quality monitor equipped with a flow-through cell.

Generally, at least three well volumes are purged using this procedure. If a well is dewatered by purging before water quality parameters equilibrate, the well will be completely evacuated and the water level recovery monitored until sufficient sample volume is recovered (approximately $57 \mathrm{~L}$ [15 gal]). If a well does not recover $57 \mathrm{~L}$ ( $15 \mathrm{gal})$ within 8 hours after evacuation of the water, a sample will be collected for volatile organic compound (VOC) analysis, alkalinity, carbon dioxide, and redox parameters, and the remaining samples collected after the minimum volume of water is recovered.

Special precautions are necessary when collecting VOC samples to prevent loss of volatiles during sampling. For collection of VOCs, $340 \mathrm{~mL}$ amber glass vials with Teflon septum caps will be filled to overflowing using a slow (less than $3.8 \mathrm{~L} /$ per minute $[1.0 \mathrm{gpm}]$ ) steady stream of water to minimize aeration. 


\section{SAMPLE HANDLING AND ANALYSIS}

The analytes of interest and the analysis methods are presented in Table 2-2. Due to the sensitivity of the carbon dioxide, ferrous iron, nitrite, and alkalinity parameters, these measurements will be made in the field immediately upon sample collection. Carbon dioxide is measured using a field titration with sodium hydroxide. Ferrous iron concentrations are measured with a colorimeter. Nitrate concentrations are calculated from a field determination of nitrite concentrations using a colorimeter and a total nitrate/nitrite measurement made at the EPA Water Quality Laboratory in Athens, Georgia. This will avoid inconveniences in the field related to the short holding time required for nitrate analysis. Alkalinity is determined by titration of a continuously stirred groundwater sample using sulfuric acid to titrate the sample to a $\mathrm{pH}$ of about 3.8. After titration, alkalinity is calculated by locating the maximum of the first derivative of the curve generated from $\mathrm{pH}$ as a function of the titrant volume. As described in Section 4, the water quality indicators are measured on-site with a flow-through cell.

Table 5-1 describes the required sample container and volume, preservation, and holding time for each analyte as described in the EPA Standard Operating Procedure (1996). Water samples collected for major cations and trace metals will be filtered through $0.45 \mu \mathrm{m}$ membrane filters into polyethylene bottles and acidified immediately to a pH less than 2.0 with ultrapure nitric acid. Samples for major anions will be filtered through $0.45 \mu \mathrm{m}$ membrane filters and are not treated with preservatives. Approximately $200 \mathrm{~mL}$ of groundwater will be filtered through $0.45 \mu \mathrm{m}$ silver filter for total dissolved organic carbon. All water samples will be placed on ice in coolers at the time of collection and repackaged with ice prior to shipment. Samples will be shipped overnight each Thursday of the sampling weeks to the EPA Water Quality Laboratory in Athens, Georgia. Any samples collected on Fridays will be stored at $4^{\circ} \mathrm{C}$ until shipment to the laboratory the following week.

Table 5-1. Sample volume, preservation, and holding time.

\begin{tabular}{|c|c|c|c|}
\hline Analyte & Container & Preservation & Holding Time (days) \\
\hline Chlorinated Ethenes & $340 \mathrm{~mL}$ VOA vials & $\mathrm{HCl}, 4^{\circ} \mathrm{C}$ & 14 \\
\hline Ethene/ethane/methane & $340 \mathrm{~mL}$ VOA vials & $\mathrm{HCl}, 4^{\circ} \mathrm{C}$ & 14 \\
\hline Chloride & 1 L Polyethylene & Filter On-Site & 28 \\
\hline Total Nitrate/Nitrite & $1 / 2$ Gallon Polyethylene & $\mathrm{H}_{2} \mathrm{SO}_{4} \mathrm{pH}<2,4^{\circ} \mathrm{C}$ & 28 \\
\hline Sulfate & $1 \mathrm{~L}$ Polyethylene & Filter On-Site, $4^{\circ} \mathrm{C}$ & 28 \\
\hline Ferrous Iron & 1 L Polyethylene & None & $\begin{array}{l}\text { Analyze } \\
\text { Immediately On-Site }\end{array}$ \\
\hline Carbon Dioxide & 1 L Polyethylene & None & $\begin{array}{l}\text { Analyze } \\
\text { Immediately On-Site }\end{array}$ \\
\hline Alkalinity & 1 L Polyethylene & $4^{\circ} \mathrm{C}$ & 14 \\
\hline Chemical Oxygen Demand & $1 \mathrm{~L}$ Polyethylene & $\mathrm{H}_{2} \mathrm{SO}_{4}, 4^{\circ} \mathrm{C}$ & 28 \\
\hline Dissolved Organic Carbon & $200 \mathrm{~mL}$ Glass & $\begin{array}{l}\text { Filter On-Site } \\
\mathrm{H}_{2} \mathrm{SO}_{4}\end{array}$ & 14 \\
\hline $\begin{array}{l}\text { Nutrients (Phosphate and } \\
\text { Ammonia as Nitrogen) }\end{array}$ & 1/2 Gallon Polyethylene & $\mathrm{H}_{2} \mathrm{SO}_{4} \mathrm{pH}<2,4^{\circ} \mathrm{C}$ & 28 \\
\hline Cations & $1 \mathrm{~L}$ Polyethylene & $\mathrm{HNO}_{3}, \mathrm{pH}<2$ & 180 \\
\hline 1,4-Dioxane & $340 \mathrm{~mL}$ VOA vials & $\mathrm{HCl}, 4^{\circ} \mathrm{C}$ & 14 \\
\hline
\end{tabular}




\section{QUALITY ASSURANCE}

The quality assurance objectives specify the analytical requirements that data must meet in order to satisfy project objectives. The precision and quantification limits for the analytical methods used are presented in Table 2-2. Quality assurance and control measures to be followed during the collection of groundwater samples are specified in the Environmental Compliance Branch Standard Operating Procedures and Quality. Assurance Manual (EPA 1996), and National Water-Quality Assessment Program (NAWQA) Ground-Water Data-Collection Protocols and Procedures (Koterba et al 1995). Duplicates, trip blanks, and equipment rinsate samples will be used at the frequency specified in Table 61. Duplicates and equipment rinsate samples will be submitted for a randomly chosen laboratory schedule. Equipment rinsate blanks will be collected through Teflon tubing used for sampling the final organic-free deionized water rinse at each sampling site. Additional rinsate samples may be collected and submitted specifically for VOC analysis after sampling wells with organic contaminants. Trip blanks for VOCs are prepared using organic-free deionized water by the EPA Water Quality Laboratory. One trip blank will be placed in each cooler used to store field samples prior to the beginning of each day's sampling activities.

Table 6-1. Quality assurance samples.

\begin{tabular}{cl}
\hline Sample Type & \multicolumn{1}{c}{ Frequency } \\
\hline Duplicate & One round of samples at one well $(\sim 10 \%)$. \\
Trip Blank & One sample per cooler for VOCs only. \\
Rinsate & Between each well or as necessary. \\
\hline
\end{tabular}




\section{REFERENCES}

Anderson, W. R. and A. K. Bomberger, 1986, Remedial Investigation Report, Distler Brickyard West Point, Kentucky, NUS Corporation, Unpublished technical report, U.S. Environmental Protection Agency Region 4, Atlanta, Georgia.

Barbee, Gary C., 1994, "Fate of chlorinated aliphatic hydrocarbons in the vadose zone and ground water," Ground Water Monitoring and Remediation, Vol. 9, no. 1, pp.129-140.

Bouwer, E. J. and P. L. McCarty, 1983, "Transformation of 1- and 2-carbon Halogenated Aliphatic Organic Compounds Under Methanogenic Conditions," Applied and Environmental Microbiology, Vol. 45, pp. 1286-1294.

Bouwer, E. J., 1994, "Bioremediation of Chlorinated Solvents using Alternative Electron Acceptors," Handbook of Bioremediation, Lewis Publishers, pp. 149-175.

Brown, R. F., and T. W. Lambert, 1963, Reconnaissance of Ground-Water Resources in the Mississippian Plateau Region, Kentucky, U.S. Geological Survey Water Supply Paper 1603.

De la Pena, G. R., 1989, Draft Revised Geologic Interpretation, Distler Brickyard Site, Hardin County, Kentucky, EBASCO Services Incorporated, Unpublished technical report, U.S. Environmental Protection Agency Region 4, Atlanta, Georgia.

Drever, J. I., 1988, The Geochemistry of Natural Waters, Prentice Hall, Englewood Cliffs, New Jersey.

Duffey, J. T., Lee, C. H., and M. Warner, 1983, Geology/Hydrology and Monitoring Well Installation, Distler's Brickyard Site, Jefferson [sic] County, Kentucky, NUS Corporation, Unpublished technical report, U.S. Environmental Protection Agency Region 4, Atlanta, Georgia.

EPA, 1994, Guidance for the Data Quality Objectives Process FINAL, EPA QA/G-4, EPA/600/R-96/055.

EPA, 1996, Environmental Investigations Standard Operating Procedures and Quality Assurance Manual, U.S. Environmental Protection Agency Region 4, Environmental Services Division, Athens, Georgia, Sections 1.0-7.11.

EPA, 1998, Five Year Review Report Distler Brickyard Superfund Site, Hardin County, Kentucky, Unpublished technical report, U.S. Environmental Protection Agency Region 4, Atlanta, Georgia.

Fekete, A. and W. S. Butterfield, 1991, Site Investigation, Distler Brickyard Site, West Point, Kentucky, Unpublished technical report, U.S. Environmental Protection Agency, Work Assignment Number 3-499, Region 4, Atlanta, Georgia.

Kepferle, R.C. and E. G. Sable, 1977, Geologic Map of the Fort Knox Quadrangle, North-Central Kentucky, Map GQ-1375, U.S. Geological Survey, Virginia.

Koterba, M. T., Wilde, F. D., and W. W. Lapham, 1995, Ground-Water Data-Collection Protocols and Procedures for the National Water-Quality Assessment Program: Collection and.Documentation of Water-Quality Samples and Related Data, U.S. Geological Survey Open File Report 95-399. 
OHM Corporation, 1989, Recovery and Injection Well Testing, Distler Brickyard EPA Superfund Site, Unpublished technical report, U.S. Environmental Protection Agency Region 4.

OHM Corporation, 1990, Basis of Design Report at Distler Brickyard Site, West Point, Kentucky, Unpublished technical report, OHM Project Number J6504, U.S. Environmental Protection Agency Region 4.

USGS, 1992, Unpublished letter to the US EPA Region 4, Atlanta, Georgia.

USGS, 1997-9, "Techniques of Water Resources Investigations, Book 9." Handbooks for WaterResources Investigations, Section A, National Field Manual for the Collection of Water-Quality Data, Chapters A1-A9, Denver, Colorado.

USGS, in preparation, Investigation of Trends in Volatile Organic Chemicals in Ground Water at the Former Distler Brickyard Superfund Site, Hardin County, Kentucky, 1995 1997, USGS Water Resources Division Draft Report.

Wiedemeier, T. H., 1997, Technical Protocol for Evaluating Natural Attenuation of Chlorinated Solvents in Groundwater, Air Force Center for Environmental Excellence, Technology Transfer Division, Brooks Air Force Base, Draft Revision 1.

Wiedemeier, T. H., et al., 1996, "Natural attenuation of chlorinated aliphatic hydrocarbons at Plattsburgh Air Force Base," New York, Symposium on Natural Attenuation of Chlorinated Organics in Ground Water, U.S. Environmental Protection Agency, EPA/540/R-96/509. 